\title{
Rainwater Management in Urban Areas
}

\author{
Brigitte Helmreich (1)
}

Citation: Helmreich, B. Rainwater Management in Urban Areas. Water 2021, 13, 1096. https://doi.org/ 10.3390/w13081096

Received: 12 April 2021

Accepted: 14 April 2021

Published: 16 April 2021

Publisher's Note: MDPI stays neutral with regard to jurisdictional claims in published maps and institutional affiliations.

Copyright: (C) 2021 by the author. Licensee MDPI, Basel, Switzerland. This article is an open access article distributed under the terms and conditions of the Creative Commons Attribution (CC BY) license (https:// creativecommons.org/licenses/by/ $4.0 /)$.
Chair of Urban Water Systems Engineering, Technical University of Munich, Am Coulombwall 3, 85748 Garching, Germany; b.helmreich@tum.de; Tel.: +49-89-28913719

\begin{abstract}
Rising levels of impervious surfaces in densely populated cities and climate change-related weather extremes such as heavy rain events or long dry weather periods provide us with new challenges for sustainable stormwater management in urban areas. The Special Issue consists of nine articles and a review and focuses on a range of relevant issues: different aspects and findings of stormwater runoff quantity and quality, including strategies and techniques to mitigate the negative effects of such climate change impacts hydraulically, as well as lab-scale and long-term experience with pollutants from urban runoff and the efficiency of stormwater quality improvement devices (SQIDs) in removing them. Testing procedures and protocols for SQIDs are also considered. One paper analyses the clogging of porous media in the use of stormwater for managed aquifer recharge. The Special Issue demonstrates the importance and timeliness of the topic of sustainable rainwater management, especially with regard to growing cities and the challenges posed by climate change.
\end{abstract}

Keywords: urban stormwater runoff; runoff pollution; sustainable urban drainage systems; evapotranspiration; managed aquifer recharge

\section{Introduction}

Urbanization has led to the disruption or replacement of natural hydrological processes due to the sealing and degrading of natural soils. Typically, stormwater runoff from sealed urban surfaces is carried away by local sewer systems and discharged to surface waters. However, this results in reduced evapotranspiration in urban areas, less cooling and blocked infiltration, and thus reduced groundwater recharge [1,2]. Strategies and techniques to mitigate these negative effects are necessary and very important for urban planning, above all because weather extremes such as heavy rain events or extensive dry weather periods provide us with new challenges for sustainable stormwater management in cities.

Additionally, the impact of stormwater runoff quality on the environment is under consideration. Sealed surfaces cause the transport and accumulation of pollutants originating from traffic areas, building materials and other impervious surfaces. A range of pollutants can be found, such as sediments (including particle-bound pollutants), bacteria, oil and grease, heavy metals, nutrients and trace organic chemicals [2-7].

Best management practices are widely applied to improve the quality of urban stormwater runoff. A variety of stormwater quality improvement devices (SQIDs) have been developed in recent years and are now being used in practice on a technical scale. Currently, there is a research focus on the performance and operation of SQIDs, but also on the development and evaluation of testing procedures and protocols [8]. However, in order to understand the processes that take place within the SQIDs, considerable research is still required to design them effectively.

This Special Issue of Water will focus on the sustainability and the environmental effects of stormwater management in urban areas. The aim was to gather papers emphasizing different aspects and findings of the monitoring of stormwater runoff quantity and quality, including new parameters. There are mitigation strategies, including models for stormwater runoff reduction, stormwater storage and evapotranspiration in urban 
catchments, lab-scale and long-term technical-scale experience, testing procedures and protocols for SQIDs, and opportunities that are available to avoid, or minimize the risks of groundwater and surface water contamination.

\section{Overview of This Special Issue}

Nine original research papers and one review article are published in this Special Issue. Three articles focus on tools to mitigate the negative effects of climate change in urban areas, namely urban flooding mitigation and modeling of evapotranspiration. Two papers have the topic of monitoring pollutant concentrations, three papers deal with the removal of pollutants from urban stormwater runoff, one paper develops a new testing approach for SQIDs and the final paper deals with the clogging of porous media in managed aquifer recharge using stormwater runoff.

There are many different urban flooding mitigation techniques available. In the review paper, Quin [9] discusses stormwater runoff reduction facilities installed above ground, underground and at the ground surface. Mainstream techniques like green roofs, permeable pavements, infiltration trenches, trees, rainwater harvesting systems, swales and others are considered. Quin [9] states that most of these techniques require sizable land areas for their construction, which are normally not available in densely populated cities. For this requirement there is a need for new developments in order to reduce peak flow.

One urban flooding mitigation technique mentioned by Quin [9] is the use of green roofs. Liu et al. [10] analyzed the influence of green roofs on the hydraulic performance of combined sewer systems and stormwater systems with respect to urban flooding reduction using a model. It was shown that green roofs not only have an enormous potential to reduce urban flooding, but also to improve evapotranspiration, which in turn can have a positive effect on urban climate.

Evapotranspiration was the main focus of Hörnschemeyer et al. [11]. A model divided into two sub-models for a precise long-term determination of evapotranspiration in cities, including shading and vegetation-specific dynamics, was developed and evaluated. The authors showed that the most sensitive model inputs were the shading factor and the crop factor. They also pointed out that there is still the research issue of improving the developed model by investigations on process dynamics, validation and parametrization.

Beside the quantitative impacts of urbanization on stormwater management, the qualitative aspects are under consideration in the Special Issue. Urban stormwater runoff is a major source of pollutants in receiving waters. Liu et al. [12] assessed the impact of stormwater runoff on an urban river in China. They analyzed various parameters, including nutrients from the runoff of different land use sites. The collection and reuse of stormwater in the initial rainfall period was shown to be effective for reducing the load of dissolved pollutants in the runoff on the receiving waters. Christian et al. [13] demonstrated that in-stream processes in urban stormwater runoff influenced pollutant load and transport when the system was viewed at a large scale. The authors compared traditional first-flush analyses to newer methods.

Different studies showed that pollutants in stormwater runoff were mainly bound to particles [3-5,14]. Consequently, particle-bound pollutants and their removal in SQIDs are the topic of three articles in this Special Issue. Baum et al. [15] demonstrated with a monitoring campaign and a subsequent analysis of different particle fractions that the highest event mean content of heavy metals were found in the smallest fraction. Currently, a particle concentration between 63 and $0.45 \mu \mathrm{m}$ (TSS63) is considered as relevant for heavy metal adsorption. Nevertheless, the authors showed that total metal loads correlated well with total suspended solids (TSS), and even better with TSS63. The TSS and TSS63 removal efficiency in SQIDs was assessed by Lieske et al. [16] using a long-term in-situ monitoring of two different devices at road sites. They showed that the mean ratio of TSS63 to TSS increased during transit through the facilities because larger particles settle better than finer ones, concluding that the finer particles are removed less effectively in SQIDs. The authors stated that a sedimentation stage was not sufficient for particle removal in SQIDs. 
An additional technique such as filtering to remove fine particles was recommended. These findings were also confirmed by Rommel et al. [17]. The authors analyzed the influence of particle density, particle shape, temperature and de-icing salt concentration on the settling behavior of road-deposited particles. Particle density and particle size distribution are the main influencing factors on the settling of particles. While de-icing salt concentration has no significant influence on the settling behavior, the temperature is decisive. In winter, therefore, particles do not settle sufficiently in the sedimentation stages of SQIDs.

To compare the hydraulic performance and pollutant removal efficiency of SQIDs, comparable test parameters and conditions must be considered, which are not available under real runoff conditions in field studies. Currently there is a testing procedure available in Germany [8] which was improved and optimized by Neupert et al. [18]. Not only the testing procedure, but also the sampling strategy was improved. A full-flow sampling was preferred compared to a discrete sampling to evaluate the efficiency of the facilities.

The article by Zhang et al. [19] is somewhat different from the previously described topics, but just as important for rainwater management in urban areas. The use of stormwater for managed aquifer recharge (MAR) becomes very important for areas with water shortage, which could also be a result of climate change. A common and significant problem is the clogging of porous filter media by iron (III). In their paper, the authors analyzed the mechanisms of clogging and retention.

\section{Conclusions}

This Special Issue collection deals with important issues related to reducing the negative impact of urbanization on the aquatic environment, especially by the sealing of urban areas and thus the change in the local water balance. Important contributions were made on the topic of mitigation of climatic stress conditions caused by heavy rain events, but also tools for the modeling of evapotranspiration in urban sites were given. From various articles on pollutants in stormwater runoff and their reduction through technical possibilities, it can be seen that there is still a great demand for research on the topic, which will certainly be the subject of further Special Issues.

Funding: This research received no external funding.

Institutional Review Board Statement: Not applicable.

Informed Consent Statement: Not applicable.

Data Availability Statement: Not applicable.

Conflicts of Interest: The author declares no conflict of interest.

\section{References}

1. Grimm, N.B.; Faeth, S.H.; Golubiewski, N.E.; Redman, C.L.; Wu, J.; Bai, X.; Briggs, J.M. Global change and the ecology of cities. Science 2008, 319, 756-760. [CrossRef] [PubMed]

2. Sheldon, F.; Leigh, C.; Neilan, W.; Newham, M.; Polson, C.; Hadwen, W. Chapter 11—Urbanization: Hydrology, water quality, and influences on ecosystem health. In Approaches to Water Sensitive Urban Design; Sharma, A., Gardner, T., Begbie, D., Eds.; Woodhead Publishing: Cambridge, UK, 2019; pp. 229-248.

3. Huber, M.; Welker, A.; Helmreich, B. Critical review of heavy metal pollution of traffic area runoff: Occurrence, influencing factors, and partitioning. Sci. Total Environ. 2016, 541, 895-919. [CrossRef]

4. Gromaire, M.C.; Garnaud, S.; Gonzalez, A.; Chebbo, G. Characterisation of urban runoff pollution in Paris. Water Sci. Technol. 1999, 39, 1-8. [CrossRef]

5. Grant, S.B.; Rekhi, N.V.; Pise, N.R.; Reeves, R.L.; Matsumoto, M.; Wistrom, A.; Moussa, L.; Bay, S.; Kayhanian, M. A Review of the contaminants and toxicity associated with particles in stormwater runoff. Terminology 2003, 2, 2.

6. Paijens, C.; Bressy, A.; Frère, B.; Moilleron, R. Biocide emissions from building materials during wet weather: Identification of substances, mechanism of release and transfer to the aquatic environment. Environ. Sci. Pollut. Res. 2020, 27, 3768-3791. [CrossRef]

7. Vega-Garcia, P.; Schwerd, R.; Scherer, C.; Schwitalla, C.; Johann, S.; Rommel, S.H.; Helmreich, B. Influence of façade orientation on the leaching of biocides from building façades covered with mortars and plasters. Sci. Total. Environ. 2020, 734, 139465. [CrossRef] [PubMed] 
8. Dierkes, C.; Lucke, T.; Helmreich, B. General Technical Approvals for Decentralised sustainable urban drainage systems (SUDS)— The current situation in germany. Sustainability 2015, 7, 3031-3051. [CrossRef]

9. Qin, Y. Urban flooding mitigation techniques: A systematic review and future studies. Water 2020, 12, 3579. [CrossRef]

10. Liu, L.; Sun, L.; Niu, J.; Riley, W.J. Modeling Green Roof Potential to Mitigate Urban Flooding in a Chinese City. Water 2020, 12, 2082. [CrossRef]

11. Hörnschemeyer, B.; Henrichs, M.; Uhl, M. SWMM-UrbanEVA: A model for the evapotranspiration of urban vegetation. Water 2021, 13, 243. [CrossRef]

12. Liu, Y.; Wang, C.; Yu, Y.; Chen, Y.; Du, L.; Qu, X.; Peng, W.; Zhang, M.; Gui, C. Effect of urban stormwater road runoff of different land use types on an urban river in Shenzhen, China. Water 2019, 11, 2545. [CrossRef]

13. Christian, L.; Epps, T.; Diab, G.; Hathaway, J. Pollutant concentration patterns of in-stream urban stormwater runoff. Water 2020, 12, 2534. [CrossRef]

14. McKenzie, E.R.; Money, J.E.; Green, P.G.; Young, T.M. Metals associated with stormwater-relevant brake and tire samples. Sci. Total. Environ. 2009, 407, 5855-5860. [CrossRef] [PubMed]

15. Baum, P.; Kuch, B.; Dittmer, U. Adsorption of metals to particles in urban stormwater runoff-Does size really matter? Water 2021, 13, 309. [CrossRef]

16. Lieske, C.; Leutnant, D.; Uhl, M. Assessing the TSS removal efficiency of decentralized stormwater treatment systems by long-term in-situ monitoring. Water 2021, 13, 908. [CrossRef]

17. Rommel, S.H.; Gelhardt, L.; Welker, A.; Helmreich, B. Settling of road-deposited sediment: Influence of particle density, shape, low temperatures, and deicing salt. Water 2020, 12, 3126. [CrossRef]

18. Neupert, J.W.; Lau, P.; Venghaus, D.; Barjenbruch, M. Development of a new testing approach for decentralised technical sustainable drainage systems. Water 2021, 13, 722. [CrossRef]

19. Zhang, H.; Ye, X.; Du, X. Laws and Mechanism of the Fe (III) Clogging of Porous Media in Managed Aquifer Recharge. Water 2021, 13, 284. [CrossRef] 